\title{
Research on Tourism Consumption and Economic Growth Under Conditions of Public Health Incident Consider Macau as an Example
}

\author{
Zhixuan $\mathrm{Li}^{1,{ }^{*}}$ Ruixue $\mathrm{Gao}^{2}$ \\ ${ }^{1}$ Faculty of Hospitality and Tourism Management, Macau University of Science and Technology, Avenida Wai \\ Long, Taipa, Macau, China \\ ${ }^{2}$ Olin Business School, Washington University in St. Louis, One Brookings Drive, St. Louis, MO 63130, United States \\ *Zhixuan Li. Email: L65236119@163.com
}

\begin{abstract}
Tourism, a very important industry for the improvement of economic and people's living standards of countries and regions, is extremely impressionable by external factors, from economic crises to public health incidents. Therefore, it is overly important to study the changing trend of tourism and economy under the influence of external factors. This study aims to extend our understanding of the relationship between tourism growth and economic development under public health incident (COVID-19) by Maslow's hierarchy of needs, Keynes's consumption theory and the consumptionsavings life cycle model. Meanwhile, this study also uses Macau as a case study to conduct a specific analysis and propose further research directions and management opinions for scholars and managers. Furthermore, this study reveals that there is bidirectional relationship between tourism growth and economic development under sudden public health incident (COVID-19).
\end{abstract}

Keywords: COVID-19, tourism growth, economic development

\section{INTRODUCTION}

According to the World Travel and Tourism Council (WTTC, 2015), the travel and tourism industry is expected to grow by about $4 \%$ annually, meaning that tourism industry has experienced a tremendous increase in the recent years and is performing well globally (Fahimi, Saint Akadiri, Seraj, \& Akadiri, 2018).[1] Meanwhile, tourism is an important industry owing to the fact that it not only accounts for about $9 \%$ of global GDP, but also is a vital source of employment and entrepreneurial vitality (Antonakakis, Dragouni, \& Filis, 2015; Koens \& Wood, 2017).[2][3] Thus, a lot of interest and research has been generated on the link between tourism growth and economic development. However, due to the sensibility of tourism industry, often even a slight risk, especially in regard to human safety, is enough to drive a sweeping change for tourism. Therefore, it is necessary to study the impact of sudden public health incidents on tourism industry and the relationship between tourism growth and economic development under the sudden public health incidents.
Moreover, this study takes Macau, which is incredibly dependent on tourism, as a case study.

\section{THE DEFINITION AND INFLUENCE OF THE PUBLIC HEALTH INCIDENTS (COVID-19)}

\subsection{The definition of the public health incidents}

Public health incidents refer to sudden outbreaks of major infectious diseases, mass unexplained diseases, major food and occupational poisoning, and other events that have caused or may cause serious damage to public health. Meanwhile, the major public health incidents such as COVID-19 typically have characteristics of being sudden, uncertain, and hazardous. In recent years, with the rapid development of economies and transportation facilities (such as air and high-speed rail), population mobility has increased, and once a major public health event occurs, it may cause significant losses to national economies and people's lives. (Jia, Guo, Wang, \& Barnes, 2020).[4] 


\subsection{The influence of the public health incidents (COVID-19)}

The United Nations Department of Economic and Social Affairs (2020) pointed out the new coronavirus may cause global GDP to drop by nearly 1\% in 2020 . Meanwhile, the World Economic Outlook issued by the International Monetary Fund in June 2020 also made the following predictions: for the United States, the second quarter GDP fell by $9.1 \%$ year-on-year, the economic growth forecast was $-8.0 \%$, and the unemployment rate was $12.9 \%$; for the Eurozone, the second quarter GDP fell by $14.7 \%$ year-on-year, the economic growth forecast is $-10.2 \%$, and the unemployment rate is $7.6 \%$. Additionally, the second quarter GDP of Mainland China, Hong Kong, Japan and South Korea grew by $3.2 \%,-9.0 \%,-9.9 \%$ and $-2.9 \%$, respectively.

\section{ANALYSIS OF TOURISM CONSUMPTION UNDER COVID-19}

\subsection{Analysis based on Maslow's hierarchy of needs}

Tourism consumption denotes to all consumption to satisfy consumers' material and spiritual needs during the period from leaving permanent residence to returning to permanent residence and the process includes receiving tourism product information, perception, choosing, decision-making, purchasing, enjoying and evaluation (Min \& Juan, 2011).

The hierarchy of needs as defined by Maslow (1943, 1970) remains one of the most impactful theories in motivation psychology and personality science (Montag, Sindermann, Lester, \& Davis, 2020). Maslow (1943, 1954) classified the hierarchy of human needs into five levels: 1) basic needs, 2) security and protection needs, 3) social needs, 4) estimation needs, and 5) selfrealization. Meanwhile, higher needs do not arise if the lower ones have not been partially met, both could be related but the basic ones will predominate over the higher ones (Allen, Muñoz, \& de Dios Ortúzar, 2019). The purpose of people traveling includes social interaction, education, physical or mental relaxation, spiritual improvement, and so on, which means that tourism is a higher level of need. Eventually, people's willingness to travel is likely to decrease by basic, security and protection threats from sudden public health incidents, such as COVID-19.

\subsection{Analysis based on consumption theories}

Li and Peng (2016) domestic tourism consumption is composed of basic consumption (accommodation, catering, transportation and sightseeing in scenic area) and non-basic consumption (shopping, entertainment, communication, neighborhood services, culture, art and others). Furthermore, the research on tourism consumption structure in the theoretical circle has not deviated from the theories and methods of the research on consumption structure in economics. Most scholars define tourism consumption structure as the proportion relationship of various types of consumption materials consumed by tourists during the travel process (Shi, 2008) and the domestic tourism consumption structure is the important indicator to measure the tourism development (Yu, 2018).

Income is made up of the net per capita disposable income of the household, the largest component of which is usually wage income, agricultural and non-agricultural commercial income, pension income, and estimated rent for own housing (Luo, Li, \& Sicular, 2020). Keynes's consumption theory provides a list of psychological motives behind consumption behavior and illustrates the relationship between consumption and income: as income growths, so does consumption, but consumption rises less than income increases (Keynes, 1973a, p. 109). Furthermore, consumption-savings life-cycle models, one of the workhorse models of modern macroeconomics (Bick \& Choi, 2013), emphasize people will plan their living consumption expenditures over a longer period of time to achieve the best configuration of their consumption throughout the life cycle. In the Keynesian short-term and consumption-savings life-cycle models long-term perspective, as the sudden public health incident (COVID-19) has reduced people's income and even people are facing the risk of unemployment, their desires to consume are also decreasing.

\section{THE RELATIONSHIP BETWEEN TOURISM GROWTH AND ECONOMIC DEVELOPMENT}

Tourism growth refer to the increase of goods and services in an economy, the increase in employment or the accumulation of capital as a result of tourism (PulidoFernández \& Sánchez-Rivero, 2010). Meanwhile, economic development is a broad concept, involving meeting the needs and demands of the resident population and improving their standard of living (Ranis, Stewart, \& Ramírez, 2000). Furthermore, the relationship between tourism growth and economic development could be divided into three different categories according the previous studies: tourism-led economic growth (Dritsakis, 2012; Ivanov \& Webster, 2013; Li, Jin, \& Shi, 2018), economic-driven tourism growth (Dragouni, Filis, \& Antonakakis, 2013; Payne \& Mervar, 2010) and the bidirectional causality between tourism growth and economic development (Hussain-Shahzad, Shahbaz, Ferrer, \& Kumar, 2017; Pulido-Fernández \& CárdenasGarcía, 2020).

Some researchers believed tourism has been seen as the most crucial source of foreign currency earnings in most of the tourist destinations in the world (Fahimi, Saint Akadiri, Seraj, \& Akadiri, 2018), due to the fact that 
the number of tourist arrivals is very beneficial for both the government and private sectors related directly or indirectly to tourism, including accommodation establishments and tourist services (Suhel \& Bashir, 2018). Economically, the number of tourist arrivals is very beneficial will stimulate consumption, increase the foreign exchange income, create tax revenue and absorb jobs to the community (Chang, Khamkaev, \& McAleer, 2010; Dogru \& Bulut, 2018; Dogru, Sirakaya-Turk, \& Crouch, 2017; Karimi, 2018; Li, Mahmood, Abdullah, \& Chuan, 2013). Conversely, other scholars suggested the application of well-designed economic policies, governance structures and investments of physical and human capital create a positive economic climate to encourage tourism growth (Payne \& Mervar, 2010). In other words, the bad economic environment could cause a negative impact on tourism industry, such as the Great Recession of 2007 and the ongoing Eurozone debt crisis that begun in 2010. In view of the results in totality, on the account of the fact that not only the magnitude but also the direction of this economic growth and tourism growth relationship changes over time, there is still no consensus on both theoretical and empirical grounds on whether tourism promotes economic activity, or economic activity leads to tourism growth (Antonakakis, Dragouni, \& Filis, 2015; Tang \& Tan, 2013).

\section{CASE STUDY BASED ON MACAU}

Macau, a popular destination for short-haul travel with arrivals of 39.4 million in 2019 (Statistics and Census Service (DSEC), 2020), incorporates a massive gaming sector and historical attractions (Chen, Suntikul, $\&$ King, 2020). On account of the colonized history and geographical locations, Macau has become a diverse tourism destination with heterogeneous culture and gastronomy, which is considered as one of the most important activities people pay attention to during the trip (Choi, Lehto, \& Morrison, 2007; Hall \& Mitchell, 2007). Meanwhile, Macau was a UNESCO Creative City of Gastronomy in 2017 (Lai, 2020) owing to the fact that there are 2284 restaurants featuring Cantonese, Japanese, Korean, and other international cuisines in an area of 30 km2 (MGTO, 2018b). Furthermore, the Macau government has also begun to develop MICE to achieve a more sustainable economy. To sum up, Macau is a city that heavily relies on tourism, so it is extremely representative in the study of public health incidents for tourism and economic development.

Affected by the anti-epidemic measures restricting the entry of tourists, the hospitality industry and economy of Macau have been hit hard. Specifically, in the first half of 2020, the gross revenue of the gaming industry fell by 95.5\% year-on-year; the quantity of inbound tourists decreased by $83.9 \%$; the number of hotel guests reduced by $73.5 \%$; the sum of conference attendees declined by $86.6 \%$; the number of exhibition visitors dropped by $86.6 \%$; the quantity of attendees at incentive travel fell by $95.8 \%$ and the retail sales decreased by $61.3 \%$ yearon-year (Macau Economic Quarterly, 2020).

The tourist consumption structure, the tourist's purpose of travel, and the tourist's consumption preferences have all changed under the influence of the COVID-19. As shown in the Table 1, 2 and 3, there are some changes concerning the tourism consumption structure of Macau, tourist structure and tourist per capita consumption on account of the COVID-19. Due to the reduction in household income under the epidemic and the impact of entry and exit policies, the number of tourists who take vacation as their tourism purpose has decreased the most compared to the same period last year. Likewise, jewelry and watches, the more expensive and non-essential consumptions, have the largest decrease in the proportion of tourism consumption structure. Besides, it can be seen that exhibition participants are also reducing their consumption in exhibitions. Meanwhile, it can be seen from Table 4 that under the influence of COVID-19, hotels with higher levels and higher consumption will be more negatively affected.

Table 1. Tourism Consumption Structure (Source of information: DSEC)

\begin{tabular}{|c|c|c|c|c|c|c|}
\hline Time & $\begin{array}{c}\text { Souvenirs } \\
\text { and food }\end{array}$ & $\begin{array}{c}\text { Cosmetics and } \\
\text { perfume }\end{array}$ & $\begin{array}{c}\text { Handbags and } \\
\text { footwear }\end{array}$ & $\begin{array}{c}\text { Jewelry and } \\
\text { watches }\end{array}$ & $\begin{array}{c}\text { Clothing } \\
\text { Other } \\
\text { Shopping } \\
\text { Consumption }\end{array}$ \\
\hline First half of 2019 & $29.7 \%$ & $27.8 \%$ & $10.9 \%$ & $14.5 \%$ & $8.8 \%$ & $8.3 \%$ \\
\hline First half of 2020 & $32.1 \%$ & $31.3 \%$ & $10.3 \%$ & $3.5 \%$ & $11.7 \%$ & $11.1 \%$ \\
\hline
\end{tabular}

Table 2. Statistics of Tourist Structure by Main Purpose (Source of information: DSEC)

\begin{tabular}{|c|c|c|c|c|c|c|c|c|}
\hline Time & $\begin{array}{c}\text { Participating } \\
\text { in the MICE }\end{array}$ & Shopping & Vacation & $\begin{array}{c}\text { Visiting } \\
\text { relatives }\end{array}$ & $\begin{array}{c}\text { Business } \\
\text { operations }\end{array}$ & Gambling & Transit & Others \\
\hline First half of 2019 & $1.1 \%$ & $7.9 \%$ & $54.1 \%$ & $3.5 \%$ & $5.0 \%$ & $3.0 \%$ & $17.8 \%$ & $7.6 \%$ \\
\hline First half of 2020 & $0.4 \%$ & $12.4 \%$ & $43.6 \%$ & $5.8 \%$ & $5.1 \%$ & $5.3 \%$ & $17.6 \%$ & $9.8 \%$ \\
\hline
\end{tabular}


Table 3. Statistics of Tourist Structure by Main Purpose (Unit: MOP, Source of information: DSEC)

\begin{tabular}{|c|c|c|c|c|c|c|c|c|}
\hline Time & $\begin{array}{c}\text { Participating } \\
\text { in the MICE }\end{array}$ & Shopping & Vacation & $\begin{array}{c}\text { Visiting } \\
\text { relatives }\end{array}$ & $\begin{array}{c}\text { Business } \\
\text { operations }\end{array}$ & Gambling & Transit & Others \\
\hline First half of 2019 & 4358 & 2549 & 2172 & 1184 & 1086 & 764 & 274 & 547 \\
\hline First half of 2020 & 3024 & 2434 & 2230 & 1092 & 875 & 1043 & 229 & 667 \\
\hline
\end{tabular}

Table 4. Average room occupancy rate (Source of information: DSEC)

\begin{tabular}{|c|c|c|c|c|c|c|}
\hline Accommodation level & First quarter & Second quarter & Third quarter & Fourth quarter & First quarter of Second quarter \\
of 2019 & of 2019 & of 2019 & of 2019 & 2020 & of 2020 \\
\hline Five stars hotel & $93.6 \%$ & $91.2 \%$ & $92.1 \%$ & $91.9 \%$ & $38.4 \%$ & $5.5 \%$ \\
\hline Four stars hotel & $89.9 \%$ & $91.0 \%$ & $89.6 \%$ & $90.3 \%$ & $43.5 \%$ & $19.7 \%$ \\
\hline Third stars hotel & $93.8 \%$ & $91.7 \%$ & $90.7 \%$ & $92.8 \%$ & $48.8 \%$ & $22.5 \%$ \\
\hline Two stars hotel & $73.5 \%$ & $75.1 \%$ & $72.6 \%$ & $74.3 \%$ & $51.6 \%$ & $33.7 \%$ \\
\hline Apartment & $64.8 \%$ & $64.0 \%$ & $59.3 \%$ & $66.0 \%$ & $53.0 \%$ & $38.5 \%$ \\
\hline
\end{tabular}

In view of the above, total tourists' consumptions in the first quarter of 2020 is only MOP 5007 million with a rate of change of $-70.4 \%$ over the same period (DSEC, 2020) and the contribution of gaming revenue to the economy (gross gaming revenue as a percentage of GDP) in the second quarter of 2020 is only MOP 3307 million with a rate of change of $-88.4 \%$ over the same period (Government of the Macao Special Administrative Region Financial Services Bureau, 2020). Furthermore, gross domestic product (GDP) has declined sharply since 2020 , specifically by $65.6 \%$ in the second quarter of 2020 compared to the same period last year. Meanwhile, overall labor unemployment rate of Macau in 2020 hit a record high in nearly five years and the unemployment rate is still increasing every quarter. By the third quarter of 2020 , the unemployment rate was $2.9 \%$ (Government of the Macao Special Administrative Region Statistics and Census Service, 2020). While the tourism industry is not developing well enough to have a negative impact on economic development, the economic downturn has also caused the government and related departments to reduce their expenditure on tourism. For example, Macau casinos have reduced the number of gaming tables ($12.8 \%$ change over the same period) and the number of slot machines (-56.9\% change over the same period).

\section{CONCLUSION}

Based on psychology and economic theories, this study finds out the negative impact of the sudden public health incident (COVID-19) on the tourism industry, and the bidirectional relationship between tourism growth and economic development under the sudden public health incident (COVID-19). Furthermore, this paper conducts an in-depth analysis using Macau as a case study.
For theoretical implication, although there have been many previous studies on the relationship between tourism development and economic development, few studies have discussed this relationship in the context of the sudden public health incident. Therefore, these findings broaden the study of the relationship between tourism growth and economic development, and provides new ideas for future studies.

For practical implication, the government and hospitality managers could find that the tourism industry has been greatly affected by the sudden public health incident. Therefore, they could formulate corresponding policies in advance to face the crisis of sudden public health incident, thereby minimizing the impact on the tourism industry. To avoid the impact on the economy (especially tourist cities), and further prevent the negative impact between the economy and the tourism industry.

\section{REFERENCES}

[1] Fahimi, A., Saint Akadiri, S., Seraj, M., \& Akadiri, A. C. Testing the role of tourism and human capital development in economic growth. A panel causality study of micro states. Tourism management perspectives, 2018, pp. 62-70. DOI: https://doi.org/10.1016/j.tmp.2018.08.004

[2] Antonakakis, N., Dragouni, M., \& Filis, G.. How strong is the linkage between tourism and economic growth in Europe? Economic Modelling, 2015, pp. 142-155.

DOI: https://doi.org/10.1016/j.econmod.2014.10.018

[3] Koens, A., \& Wood, R. C. An analysis of international employment levels in hospitality occupations using secondary statistics. International 
Journal of Tourism Research, 2017, 19(5), 496-504.

DOI: https://doi.org/10.1002/jtr.2122

[4] Jia, Q., Guo, Y., Wang, G., \& Barnes, S. J. Big Data Analytics in the Fight against Major Public Health Incidents (Including COVID-19): A Conceptual Framework. International journal of environmental research and public health, 2020, 17(17), 6161.

DOI: https://doi.org/10.3390/ijerph17176161 